\title{
GROUNDING COMPLEXITY ECONOMICS IN FRAMING MODERN GOVERNANCE*
}

\author{
Olivér KOVÁCS \\ (Received: 15 January 2018; revision received: 26 March 2018; \\ accepted: 4 April 2018)
}

This paper addresses the hottest potato of economics today, namely why the profession seems to have been lulled into a sense of false security in spite of flourishing economic models as well as subfield-knowledge in various disciplines? The embarrassing question of the Queen of England 'why did nobody see the crisis of 2008 coming' emblematically signalled the failure of the collective imagination of the entire profession to understand the system and its emerging patterns. The present paper can be seen therefore as a clarion call for grounding a shift towards an economics barded with the lessons learnt in complexity science in shaping modern governance.

Keywords: complexity, complex system, uncertainty, economic governance

JEL classification indices: B10, D8, E60, H00, P50

* This paper was supported by the János Bólyai Research Scholarship of the Hungarian Academy of Sciences and by the UNKP-19-4-NKE-2 New Excellence Program of the Ministry for Innovation and Technology.

Olivér Kovács, senior research fellow, National Univesrity of Public Service, Faculty of Public Governance and International Studies, Department of Economics and International Economics; ICEG European Center. E-mail: Kovacs.Oliver.Istvan@uni-nke.hu, Web: http://oliverkovacs.com 
„We will have to deal with the complexity we have discovered.

But this very complexity will lead to new disciplines, which will help us to transfer our knowledge from one domain to another. Perhaps the challenge of these coming years will be to master complexity."

Ilya Prigogine

\section{INTRODUCTION}

For a long time, economic practitioners believed that we have reached the age of comfort in terms of economic governance. Robert Lucas, a Nobel Laureate in economics, triumphantly stressed that the tempestuous times are now belonging to the past because macroeconomics has succeeded: Its central problem of depression prevention has been solved, for all practical purposes, and has in fact been solved for many decades (Lucas 2003:1). Then the traumatising impact of the 2008-2009 global financial and economic crisis forced economics profession to 'stop for a word'. The embarrassing question of the Queen of England 'why did nobody see the crisis of 2008 coming' emblematically signalled the failure of the collective imagination of the entire profession to understand the system and its emerging patterns. It is hardly by chance that when other prominent scholars, the Nobel-Prize winners Thomas J. Sargent and Christopher Sims were asked at dinner after the Nobel Prize ceremony in 2011 about what their lifeworks convey about the recent crisis, the answer was nothing but silence. It has become clear that when fire station burns down, our models become insufficient in time of enormous instabilities. Consequently, in the light of such annoyingly unanswered questions, there is a growing incredulity at prevailing economics (Csaba 2009; Coyle 2012; Zingales 2013; Galbraith 2014; PCES 2014; Keen 2017).

Our paper proposes the audacious claim that some questions are not only embarrassing, but also unanswerable due to our limited understanding of their embeddedness into the complex system we live in. For example, should we remove Greece from the Eurozone or help the debt-ridden country to remain? Shall we increase EU budget or create further funds to build up a transfer system? Which is more important in proper crisis management, fiscal or monetary policy? Shall the state inject ever-more financial support into the economy to spark digital transformation even though the productivity growth has been secularly declining despite the unprecedented level of digitization of today? Which regions (more advanced or less developed) should be primarily targeted via state transfers and other support programmes by taking into account the side-effect of increasing inequalities as well as the limited fiscal room for maneouvre? Is it really rationale to support and pick up gazelles (fast-growing firms), though being a late comer can also be advantageous both for the firm and for the macroeconomy through exaptation? 
Some even called for a thorough revision of economics to restore its beacon role in understanding what is really going on in the economy. Our paper, without being exhaustive, is to demonstrate that crises and scandals do not mean that the science of economics is in the shade of intrinsic failure. Most of the problems occurred because we ignored what we once knew about the economic system by merely cherishing deeply ingrained and seductive assumptions. As a corollary, a complexity-aware economics is blatantly needed to better map the interactions in grasping what in heaven and hell is really going on.

\section{FROM PARMENIDES TO HERACLITUS - COMPLEXITY AND COMPLEXITY SCIENCE?}

From the dawn of civilisation, mankind has been seeking for and wanting to see certainty. There was a time of classical science when questions like 'Which events will remain without substantial repercussions?', 'What kinds of interactions will shape the entire functioning of the big system?' or 'Which event can repel us towards irreversible changes?' never occured across the board. At that time, analysing the laws of res extensa, that is to say, the natural (physical) world over the res cogitans (a world with human mind) was dominating with the logical consequences of assuming determinism and timelessness (time-reversibility) together with stability and equilibrium. In fact, that ideology summoned the central worldview of the ancient Greek philosopher Parmenides who was resolutely arguing that change is impossible and all kinds of existence in the universe is timeless. That Cartesian Zeitgeist gave the impression that certainty is everything, and since certainty equals with truth, the ultimate goal of science is to find truths (universal laws). ${ }^{1}$

There were three interlinked assumptions grounding classical science. First is determinism and equilibrium. Laplace's famous demon is equipped with the lapis philosophorum to overlook ex ante and ex post the system and to predict the future. It gave a misleading feeling of comfort that time (and its consequence: irreversibility is negligible), thus concentrating only on structures rather than also involving the processes and relationships is an instructive way forward. Second is reductionism, which builds to a great extent on the Aristotelian and Ockhamian logic,

Let us recall the mechanistic and atomic worldview of Pierre Gassendi or that of Galileo Galilei in the 17th century, who all thought that the universe is written in the language of mathematics, hence measurement is inevitably everything and the world can be fully described and known by 3-4 or maximum 5 fundamental laws (e.g. Newton's laws of mechanics (1686), Maxwell's laws in electrodynamics (1864), Boltzman's laws in thermodynamics $(1872 / 1875)$, Einstein's general relativity theory $(1905,1915)$, and the laws of quantum mechanics (Schrödinger, Heisenberg and Max Born)). 
namely that our theories must in any case embrace as few things as possible. It also assumed that the whole is completely knowable via analysing its parts per se. Third is separability or disjunction, which was a critical boost to the development of silo-thinking (i.e. the evolvement of specific and hermetising scientific disciplines having no intention to obtain ideas and knowledge outside their walls).

Albeit there was another Greek philosopher Heraclitus, whose ideology of dynamism and constant time-depentent change was in diametrical opposition to the Parmenidesian logic, his worldview had only been lurking in the shadow of scientific development through the centuries waiting to be re-discovered. The legacy of the Parmenidesian worldview was traceable in the conceptual frameworks of quantum mechanics as well as that of the theory of relativity by ignoring the arrow of time and the irreversibility principle described comprehensively later on by interdisciplinary researchers ${ }^{2}$ (i.e. there is no preferred direction of time, there is time-reversal symmetry in quantum mechanics, while there is the spacetime continuum in general relativity). Natural sciences allied together to find a unified theory of everything (connecting the micro-world's laws to that of the macroworld), but it seems to be a futile undertaking once structural and procedurial complex changes are also considered. For a long time, this equilibrium-centric view of understanding with the underlying core assumptions indicated above neglected the de rigeuer aspect of non-equilibrium interspersed by interactions and emergence in complex systems. ${ }^{3}$ Thus, a more complexity based scientific approach started to unfold with system thinkers but only with a great inertia. ${ }^{4}$

If Parmenides once represented statism (being), Heraclitus manifests in system thinkers incorporating dynamism and change (becoming). Systemic thinking gained traction in the $20^{\text {th }}$ century in a more vigorous way inter alia in the organismic biology, Gestalt psychology, chemical kinetics, ecology, complexityinformed sociology and even in economics. Since natural and social sciences deal with living systems alike, the analysis of the relationships among the parts started to garner much more attention with time, especially when structural change is to be better understood.

2 The oeuvre of Ilya Prigogine (1945, 1984, 1987), a Nobel-laureate in chemistry, exemplifies this. His research was continuously castigated by the prominent representatives of his narrow discipline, but his work proves that interesting findings come from starting a siege against the conventional walls of a particular field.

3 By now, there is an increasing body of evidence about the arrow of time, what is more, about the relative nature of the arrow of time (Haramein et al. 2016).

4 The term 'complexity' gained momentum mainly in information theory, general systems theory or in the Norbert Wienerian cybernetics, however, scholars still idolized the cult of disciplinary narrowness. See the works of von Neumann and von Foerster, and for a comprehensive account on hysteresis Morin (2007). 
Briefly and succinctly, complexity means dependent entanglement among the large number of parts continuously interacting with each other. In a complex system, macro patterns are emerging from the interactions of constituent agents (examples for complex systems are the universe, climate, living-organisms, ecosystems, human cognition system, society and culture, organisations, cities, traffic, etc.). Let us note that a well defined and coherent complexity science is a nonexistent category. Still, there are amalgams of concepts deciphered along the decadeslong course of complexity thinking in various fields dealing with such systems.

The warp and woof concepts of complexity science, at least, can be juxtaposed as follows. Complex systems (1) have an interactive network of interdependent parts (agents), where adaptive agents and the system itself are co-evolving by interacting each other in grounding self-organisation; (2) are pervaded by feedback mechanisms interspersed with cumulative and reflexive causation and making the whole to be different from that of the mere sum of the parts; ${ }^{5}$ and (3) are ruled by Heraclitus in the sense that there is emergence (becoming). As a consequence, complex systems exhibit (4) non-linear processes cultivating far-from equilibrium situations (turbulences) ${ }^{6}$ leading to fluctuations or instabilities (bifurcations) when qualitative structural changes emerge that are per se disproportionate and unpredictable; (5) are characterized by chaos-theory based sensitivity ${ }^{7}$, when even small changes can trigger big cascading or escalating effects, that is to say, micro fluctuations can have transformative macro effects; they therefore have history; (6) are non-ergodic systems in which the arrow of time and its irreversibility consequence prevail by being the creation mechanism of order out of chaos (when critical instability is organised), in other words, to evolve via structural changes. ${ }^{8}$

5 For more than 135 years, the famous female German scientist, Amalie "Emmy" Noether described her theorem about symmetry in nature, which is of paramount importance here if for no other reason than that Noether's theorem suggests that a complex system is by no means equal with the sum of its parts, but the sum of its parts taken with the interactions among them.

6 Leonardo da Vinci was the first who addressed turbulence in 1508-1513 (Monaghan - Kajtar 2014).

7 For a recent comprehensive account on the mastermind behind chaos theory, see Henri Poincaré, a French mathematician, physicist, and philosopher (Verhulst 2016).

8 Using the term of complexity research, there is Self-organized Criticality (SOC) in a complex system like socio-economic system that may easily possess a self-organising attractor state that has an inherent potential for abrupt irreversible transitions of a wide range of intensities (Bak et al. 1988). As Prigogine (1984) claimed, the irreversibility of time is the mechanism that brings order out of chaos, from chaos, which is an unstable order. The concept of ergodicity was developed and cultivated at a time of mechanistic worldview, especially in statistical mechanics to overcome some problems. See the works of Birkhoff (1931) or von Neumann (1932), who came to the same conclusion. 
Without being exhaustive, the above elaborated features of complex systems have many important implications for a broad array of scientific fields. (1) Eliminating the interactions from analysing various phenomena in systems is doomed to fail since it would ignore the paramount importance of the dynamic configuration of processes which sustains and maintains structures. ${ }^{9}$ (2) Since non-linear interactions are likely to nourish fluctuations and instabilities, non-equilibrium is the norm rather than the exception, thus the system is exposed to radical contingency, i.e. there is a great fundamental uncertainty in complex systems. ${ }^{10}$ Removing the terms of 'ceteris paribus', 'solutions', 'exogenous' (shock), 'standard' or phrases like 'what matters the most is' or 'standard policies' from our dictionary is in order when it comes to dealing with complex systems. (3) A low level of volatility in a complex system is a harbinger, or often a clear manifestation, of decay (crisis). ${ }^{11}$ (4) When systems change, the mathematical models and the equations suggesting final solutions lose their explanatory power and fail because outcomes are not mathematical ones, but patterns (e.g. in economics, no practical and coherent mathematical model is capable of describing the full range of effects of the invention of steam engine or the industrial robots because the entire configuration of the system changes).

Importantly, it would be naivitae to think of complexity science having a unified and coherent, hence static structure. A singular complexity science would be a perverse ouroboros because the very essence of complexity science is to address dynamism and emergence, thus its field, by very nature, must be a dynamic one pervaded by a panoply of various fields and concepts grasping complexity in an interdisciplinary fashion (e.g. computational modeling, big data, agent-based modeling, network analysis, socio-cybernetics, econophysics, socio-physics, chaos theory, systems theory, linkages and globalised world development, etc.). In this sense, complexity science is not to provide a unified theory, but an ontological framework when it comes to dealing with complex systems, like socioeconomic innovation ecosystem.

9 Poincaré asked whether we can eliminate interactions, and Prigogine (1990: 8) showed that it cannot be the instructive way forward once we want to better understand coherence and structural change in time in case of complex systems. This insight cannot be ignored in physics any longer, since modern physics started to emphasise that matter has lost its tangibility with more and more inward research and discoveries (matter into atoms, atoms into sub-atomic particles, sub-atomic into quantum fields and forces. Mass has no longer a primatus. Mass is the result of interactions among intangible quantum fields (Bagott 2017).

10 Fundamental uncertainty originates in quantum mechanics elaborated by Werner Karl Heisenberg, who developed his indeterminacy principle or uncertainty principle (Umbestimmtheit, Umsicherheit) stating that by measuring we are creating events since we are part of the system and our measurement affects what we measure.

11 A system in full equilibrium and stability is inevitably a dead system (Capra 1996). 


\section{COMPLEXITY IN OUR SOCIO-ECONOMIC SYSTEMS}

By now, economics profession is quite able to understand where the economy was 10 years ago, but there is a good deal of uncertainty over what is really going on now. The chain of interconnected and intertwined challenges, the intensifying interaction of various players have been making our system ever-more complex by limiting our ability to predict crises as indicated in the introduction.

Some argue that this shortcoming is given because the entire profession neglected the obvious that our socio-economic ecosystem is a living complex system of subsystems. People, organisations, institutions embedded in the environment are the main constituents of our socio-economic ecosystem by perpetually interacting with each other and creating emerging patterns mainly through nonlinear network phenomenon (network phenomena are, for example smoking, crying, wealth, poverty, bank lending, non-complying loans, crashes, European integration, etc.). ${ }^{12}$

Section 3 aims at (1) deciphering whether we neglected what we already knew by taking an illustrative historical overview of the development of complexityaware economic thinking along the last two centuries (i.e. the ideas of the most influential economics thinkers are matched with the messages of complexity science described in the previous section); and (2) demonstrating why there is still a need for relatively new lenses of complexity to address what is really going on in the socio-economic ecosystem showing ever-more complexity. ${ }^{13}$

\subsection{The duel between Parmenidesian and Heraclitusian economics}

The following short historical account on scientists and economists validates, to a great extent, our claim that there has always been some sort of predilection in economics to overcome simplicity (i.e. to see the complex system with its nuances in the spirit of Heraclitus). Unfortunately, economics had inclined to think of nouns (i.e. long-lasting structures) instead of verbs (changing processes and interactions in the system) for a long time in a Parmenidesian sense. The economy was not primarily considered as a complex, but just a complicated system that can be totally understood and governed by relying on simplified and stylised models,

12 It is hardly by chance that Heisenberg stated (1958: 65) that "The world thus appears as a complicated tissue of events, in which connections of different kinds alternate or overlap or combine and thereby determine the texture of the whole."

13 Since complexity science is the amalgam of different approaches having the same gradient towards dynamic systems with constantly evolving properties and patterns, not all such theories and concepts are adaptable to social inquiry. See more on this by Byrne - Callagham (2013). 
based on methods of natural sciences (e.g. physics), applied to a closed economy or its particular sector. Still, one can find dissonant voices in the works of prominent scholars and economists. ${ }^{14}$

Thinking about basic questions of Adam Smith (where does wealth come from, how wealth is distributed), Léon Walras turned to an economic approach dominated by mathematical language simply because of his firm belief in perfect free competition requiring abstract presumptions (e.g. no trade out of equilibrium) and disregarding reality of the production process. ${ }^{15}$ Compared to Walras, Alfred Marshall recognised the fundamental flawness Walras (and others) made: "It may be well to insist again that we do not assume that competition is perfect. Perfect competition requires a perfect knowledge of the state of the market [...]" (Marshall 1920: 540-541). Despite the still abstract assumptions, Marshall tried to capture the trading process in real time by not denying the relevance of far-from equilibrium. Nevertheless, his contribution still had a bias towards considering partial equilibrium, merely. As Joseph A. Schumpeter came to the scene as a non-technical, verbal economist, the then-fashionable mathematical economics was challenged for a moment. As opposed to Walras and Marshall, Schumpeter addressed the side of production as well by building on a more holistic approach making entrepreneurship and its innovation activity, that spark productivity and wealth, to be the focal point of analysis. In this way, dynamic order, the process of becoming via changes was incorporated (creative destruction). Nonetheless, economists of that time were still about to approach economic issues in a mathematically coherent way (building on the assumptions of rationality, general equilibrium). ${ }^{16}$ Schumpeter's innovation was therefore considered by mainsteam economists only as an exogenous variable (and his works were not taught at Berkeley).

14 As Ha-Joon Chang emphasised at a conference in Budapest, Hungary in March 2018: only a third of the 9 major schools of economics look at the world as complex and uncertain system. See, for example Chang (2014). Our paper, without being exhaustive, mainly refers to those influential representatives of various schools whose understanding can be more or less matched with the messages of complexity science.

15 Walras believed in some sort of universal force arranging the system towards equilibrium all the time (Walras 1900,1954). What is more, as Reaume (1996:147) demonstrates in a book edited by David Colander who was one of the first advocates of the changing face of mainstream economics, in a Walrasian approach, the whole is just the sum of its parts. As a corollary, the influential role of interactions is not taken into account (e.g. for Walras, entry onto the production side is unlimited, however, this is not really the case).

16 In his review on the theory of perfect competition, Stigler unravelled the unrealistic feature of the concept, but also showed the dominant use of it by mentioning: "[...] it has proved to be a tough and resilient concept, and it will stay with us in recognizable form for a long time to come." (Stigler 1957: 17). 
One of the reasons behind preferring the general equilibrium principle further on was that, as in natural sciences as well as the Parmenidesian-logic dictates, mainstream economists were to decipher time-dependent universal laws and regularities in the economic system. This kind of entrenched belief or goal was challenged by some system thinkers but with a very limited echo effect in the circle of mainstream economics. For example, the father of Ordoliberalism, Eucken (1949) stressed that theories pursuing universal statements are nothing but lameduck attempts. ${ }^{17}$ Another equally important figure of the German Ordoliberalism was Röpke (1950), who also underlined the crucial importance of fundamental uncertainty into the system by stating: "No idea, no opportunity that could be excluded. No distinct boundaries, no unalterable points, no rigid fundaments that could stabilise [...]. Any kind of behaviour of individuals and governments is conceivable; we shall be prepared even for the most absurd and abnormal thing." (Röpke 1950: 58-59)

Albeit the giants of economics, Hayek and Keynes sometimes seemed to advocate thoughts being within the paradigm of general equilibrium (i.e. pursuing a stable full employment equilibrium). They both believed in the endogenous nature of business cycle and offered a fertile ground for a more complexity based economic thinking. Some of their alarming considerations fell on deaf ears, especially when they emphasised complexity-related features that are heavily affecting macro outcomes and, as Hayek said, patterns ${ }^{18}$ (e.g. the non-negligible character of time horizon for decisions; the cognitive shortcomings of heterogeneous and interacting agents, hence their limited knowledge and foresight; the role of emergence (becoming as 'spontaneous order') ${ }^{19}$ and the fact that the whole is much more than the sheer sum of its parts). Unsurprisingly, due to the inexhaustible complexity of the ecosystem, the Hayekian view favours rule-following and cautious governance over extensive discretionalism (i.e. avoiding the pretence of perfect and complete knowledge is of essence in the case of complexity and

17 These theories would totally neglect the nuances of the world and the psyche of people (all things people do can have unintended negative consequences departing the system from equilibrium by invalidating universal theories). The world must be, as John Stuart Mill emphasised (Mill 1859|2001: 89), a mix of different opinions, perceptions where individuality should be deliberated and pursued to reach out wellbeing. This organically brings fluctuations into the system.

18 Seeking 'laws' in complex systems, which economics has to deal with, is a futile undertaking and the whole aspiration is probably the result of inductivism. See this argument in Hayek (1967).

19 See: Hayek (1945). Let us note that the concept was also recognised and promoted, but sadly overlooked by the wider public, by another verbal economist, Michael Polanyi at that time. See Polanyi (1939) or for a more general account on the ignorance of Polanyi see Jacobs (1998). 
high uncertainty) (Hayek 1960, 1974). Even those remarks of Keynes did have an instant and immediate effect on the overly sanguine view about using comparative statism in which he questioned the approach by calling for the incorporation of complex and incommensurable magnitudes (Keynes 1930, 1971) (i.e. to take into account dynamism and fluctuations (emergence) generated mainly by heterogeneous expectations of various agents, the intrinsic difficulty of quantification in a complex and open system leading to limited knowledge, organic interdependence in the network of agents that tend to show 'animal spirits' by creating instabilities $\left.{ }^{20}\right) .{ }^{21}$ Still, at that time, the equilibrium and stability centric views of the mainstream remained resistant to such considerations. Nonetheless, years later, as Ferrari-Filho and Conceição (2005) or Rosser (2006) pointed out, post-keynesian economists and institutionalists started to enshrine the idea of disequilibrium and the central importance of fundamental uncertainty.

In addition, the classical postulate of rational expectations was not without discordants even at the birth of the concept, either. True, the term was coined by Muth (1961) in his seminal paper and the concept was put into the centre of the neoclassical synthesis and that of mainstraim economic models, Muth himself and the Nobel-laureate system thinker, Herbert A. Simon, explicitly expressed their concerns that there is a huge discrepancy between theoretical rational expectations and the way the economy actually works. ${ }^{22}$ Despite the growing body of evidence about the shortcoming of the concept, it lived its mainstream life later on (mainly by assuming that there must be rational expectations at the aggregate level of the society, however, there has been no model so far that could properly address the learning process whereby the assumed convergence to rational expectations equilibrium can emerge). ${ }^{23}$

It lasted for decades then until the profession started to consider agents (individuals, households, firms, even institutions) as rational players but having merely limited and local knowledge. ${ }^{24}$ For example, although Kenneth Arrow is touted as one of the most influential founders and developers of mathematical economics interspersed with equilibrium orientation, it is often neglected that his work at the same time was pervaded by a soupçon of alarming by noting the limitations

20 The incredulity at the approach of Keynes might be of importance, however, criticism must be refined if all the notes are considered in Chapter 18 of The General Theory, when Keynes admits that variables are constantly changing, "hence the extreme complexity of the actual course of events" (Chapter 18: 249).

21 Keynes $(1936|1973,1921| 1973,1930 \mid 1971)$.

22 Simon $(1962,1978)$.

23 It depends on whether positive or negative expectations feedbacks are considered (Assenza et al. 2014: 61).

24 See more on this agent-based literature Epstein (2007) and LeBaron (2006). 
of rational expectations and by claiming satirically that people must be superior statisticians to the future general equilibrium (Arrow 1978:157-169). ${ }^{25}$ An undeservingly underrated contribution in this regard was Krupp (1966), whose essays acknowledged complexity (and unknowables) in a more vigorous way, such as Kenneth E. Boulding (1966), whose socio-economic understanding was holistic by giving special attention to the open, dynamic character of the economy as well as to the essence of memory (psychic capital) either in the real economy or in the financial sector. ${ }^{26}$ Psychic capital, as a dynamic concept, is exposed to and can be a driver of fluctuations or feedbacks known from system theorists. What is even more important is that, despite all readible efforts of Adam Smith in offering a more or less dynamic view implying a great potential of feedback system (Mayr 1971), and despite the reappearance of the term 'feedback' in the 1940s partly sparked by the development of other scientific disciplines ${ }^{27}$, incorporating the concept in the field of economics had remained rather limited until recently. ${ }^{28}$

Nonetheless, in the beginning of 1970 s, mainstream economists were still a staunch supporter of building ever-more complicated econometric macro-models, economists like Robert Lucas, Finn E. Kydland, Edward C. Prescott, Thomas J. Sargent and Robert M. Townsend made general equilibrium central to macroeconomic thinking. However, the real performance of these models remained abysmally low, especially with the advent of oil crises. There were some economists proposing that the prevailing macroeconomic thinking be broadened (e.g. taking into account not only nominal rigidities and the interest rate instrument, including also other distortions, etc.), their flair, in turn, was rather moderated

25 In addition, Arrow tried to be the 'arrow of time' by stimulating younger scholars to start thinking and modelling about asymmetric information in the perfect competiton framework. See the works of Robert J. Aumann in fields of game theory, whose interest was strongly propelled towards such imperfection.

26 Psychic capital, coined by Boulding (1950:140), embraces memories of pleasure, success, achievement, recognition as well as memories of failures, disasters, atrocities, or perceived injustices and indignities. It, thus, influences expectations, decisions of agents and, of course, the public support of economic policy actions. This is why precise prediction in social system is rather limited, and mostly impossible.

27 Norbert Wiener and his co-authors inspired many scientists to address feedbacks (See: Rosenblueth et al. 1943). For example, Gregory Bateson or Margaret Mead in anthropology, Warren S. McCulloch in neurophysiology and cybernetics, Wolfgang Köhler in psychology, and John von Neumann in mathematical economics.

28 See the reflexivity principle introduced by Soros (2003), which is about mutual and non-linear dependency via forward and backward linkages. System thinkers, like Capri - Luisi (2014) expressed the concept by saying that we cannot understand the dynamics of the human heart in terms of the interactions of its cells because the behaviour of every cell depends on the overall state of the heart itself. Causality works in both directions. 
at the level of the basic neoclassical model. ${ }^{29}$ The forward looking and rational homo economicus (representative agents) living in a Parmenidesian equilibrium world continued to be the favoured modelling framework.

As the renowned psychologist, Daniel Kahneman (2011) showed, people simply cannot live in a state of perpetual uncertainty, therefore there is a bias to make up the best story possible and we live as if the story were true. This was partly behind the belief that economic governance and economics could develop the theories and tools with which the economy is manageable, and the era of Great Moderation (approximately between 1992-2007) was a result of such progress. In fact, with a complexity-aware mindset, the era of low volatility can be considered as a signal of encoding instability. ${ }^{30}$ With the eruption of the 2008 financial and economic global crisis and its ensuing Great Recession, models like the most beloved dynamic stochastic general equilibrium models (DSGE) ${ }^{31}$ ignoring crucial aspects (e.g. heterogeneity, becoming, financial system, psychological findings, etc.) ${ }^{32}$ were admittedly proved to be "seriously flawed" (Blanchard 2016) undertakings in explaining what is really going on in the ever-more complex economy. ${ }^{33}$ This confession per se indicates that complexity should be better integrated in the future, or, at least, the diversity of macro models is needed because we have different tasks to be done. ${ }^{34}$

Some sort of awakening in macroeconomics has been started among mainstream economists: acknowledging imperfect knowledge about the complex socio-

29 See Shackle's works $(1967,1976)$ for incorporating time, becoming and some sort of memory into the models. See the well-known Hungarian system thinker's work, Kornai (1971|1990) calling for disequilibrium-research, or the paper by Diamond - Dybvig (1983) focusing on disequilibrium by studying bank panics and financial crisis, Bernanke - Gertler (1989) devoting special attention to financial fluctuations, Holmström - Tirole (1998) incorporating aggregate uncertainty on liquidity analysis or Erceg et al. (2000) presenting a model with a more monopolistic competition. On why the mainstream remained so resistant, see: Csaba (2017).

30 Low level of volatility in case of complex systems (interactive systems) can be a trouble sign too (Arthur 2015).

31 Christiano et al. (2017) wrote a contemporary apologia in favouring DSGE models, however, the authors fall short in explaining the sustainability and powerfulness of such models if reality is to be grasped. See: http://bruegel.org/2017/12/the-dsge-model-quarrel-again/ (Accessed on: 26.03.2018)

32 See the shortcomings of the micro based macro modelling, Gertler - Kiyotaki (2015), or Gatti et al. (2010).

33 See the critique of mainstream economists: Blanchard et al. (2010). Even the simpler models were more able to explain what is happening and to make some predictions, see the comprehensive paper of Gürkaynak et al. (2013).

34 See: Blanchard - Summers (2017) or https://piie.com/blogs/realtime-economic-issues-watch/ need-different-classes-macroeconomic-models (Accessed on: 26.03.2018) 
economic system ${ }^{35}$; incorporating more and more features of complex systems into our models (e.g. emergence in the form of qualitative structural change via techno-economic paradigmatic shifts ${ }^{36}$, behavioral dynamic heterogeneous agent models that consider boundedly rational agents and non-linearity as well ${ }^{37}$ ); and encapsulating the financial world and the psyche which is of key importance. ${ }^{38}$

Our rudimentary overview has so far illustrated that complexity-consciousness has been by no means a rare asset in economics, rather a mostly ignored one. Consequently, today's economics should not neglect what we once knew. Yet, our paper argues that there is still a substantiated need for new lenses of complexity to address what is really going on in the ever-more complex ecosystem.

\subsection{Beyond tilting at windmills - towards a Heraclitusian Economics}

As Heraclitus argued, opposition brings concord. However, whether the former and present-day system-minded economists can jointly overcome tilting at windmills by triggering a paradigm shift in the fiendishly resistant mainstream economics is still an open question. Based partly upon our previous historical overview we argue that shifting towards complexity economics is inevitable because

35 For example, see the stream of imperfect knowledge economics marshalled by Roman Frydnam and Michael D. Goldberg $(2007,2011)$ which reinterprets the Knightian uncertainty. Another mainstream economist, Paul De Grauwe proposes complexity-aware macro modelling by acknowledging the dynamic patterns evolving along the state-market co-evolution cycle (De Grauwe 2017). By the same token, the distinguished Polish economist, Grzegorz W. Kołodko (2011, 2014a, 2014b) also calls for analysing changes rather than states via new pragmatism.

36 The theory of techno-economic paradigm means that since the beginning of the Industrial Revolution in England in the 18th century, socio-economic development has a cyclically evolving pattern driven by technological revolutions (Big Booms) (followed by installation and deployment phases) by forming qualitatively anew techno-economic paradigm (Perez 2009; Kovács 2015). The latest ICT-based service-oriented techno-economic paradigm started to evolve in the 1970s, and it is now the context sparking the so-called fourth industrial revolution and the digital economy.

37 Strategies changing evolutionarily by leading to steady states and leaving them towards dynamic, complex chaotic dynamics via reflexivity, that is to say, how micro fluctuations are amplified onto the macro level by triggering changes in macro patterns (Hommes 2013, 2016). In agent based behavioural models, agents try to cope with complexity by adaptive learning (i.e. refining simple heuristics) when it comes to forecasting.

38 This was acknowledged even by one of the most cited economists, Andrei Shleifer, a neoclassical mainstream economist, who studied the psychology of the financial crises (Gennaioli et al. 2015) being undeniably influenced by the work of Daniel Kahneman (Shleifer 2012). About capturing the increasing complexity in the financial system, see Battiston et al. (2016a). 
of the ever-more intensifying complexity pervaded by interwoven wicked challenges.

Globalisation, and digitalisation as its carrier mechanism, has led to ever-more increasing number of nodes and inter-linkages, while the nature of inter-linkages has also been changed, not to mention the fact that the speed at which a stimulus or shock propagates to other nodes has been much faster in today's socio-economic complex system.

One of the thorniest challenges of the world economy today is the widely perceptible backlash against globalisation. Many people feel that they have been left behind and the globalisation machine does not seem to be working for all (i.e. more and more stranded communities, maldistribution of benefits of the globalisation). The consequence of this is the weakening trust and confidence in national and supranational governance, ultimately, in current economics.

The backlash against globalisation, meaning increasing criticality for governance, that is to say, the ailing trust in current economics is due to the complex interplay among intertwined challenges:

(i) secular stagnation (lowering productivity growth implying weakening innovation performance since the 1970s); ${ }^{39}$

(ii) demographic challenge (e.g. ageing population with shrinking active labour force in developed countries, while increasing labour force in developing countries; increasing income and wealth inequalities and impoverishment in the developed countries); ${ }^{40}$

(iii) climate change (air pollution, intensifying weather anomalies, increasing temperature, etc.);

(iv) broken harmony between financial sector and the real economy (i.e. deliberating globalising financial sphere was with the objective of achieving 'infinite' capital mobility in space and time, financial system then figured out that there is no need for the real economy to realise profits,

39 Average growth rate of the U.S. and that of the EU was $4 \%$ in $1950-1960$ s, it then slowed down, and the potential growth has become approximately $2 \%$ by the 2010 s, merely. Wages have been mainly stagnating as well discouraging more risky innovations (Nolan et al. 2016). Despite shortcomings in measurement, productivity slow down is out there (Byrne et al. 2016). Moreover, Bloom et al. (2017) pointed out that today's productivity growth is reached out by 20 times more researchers than before the 1970s. See more on secular stagnation: Gordon (2012), Teulings - Baldwin (2014).

40 As OECD (2017a) conveys, in OECD countries, the average income of the top 10 per cent has increased to almost 10 times that of the bottom 10 per cent, up from seven times in the mid1980s. The richest one per cent own 19 per cent of global wealth, while three per cent is shared between the poorest 40 per cent. Plus, the decreasing trend in relative poverty in high-income countries has become rather anaemic and even stalled since the Great Recession (Ravallion Chen 2017: 32). 
it has become a self-propelling mechanism and the financial sector does not seem to be an efficient intermediator any longer but it has been showing a parasite-like behaviour by becoming a financial casino); ${ }^{41}$

(v) changing characteristics of emerging markets (i.e. becoming more service and consumption driven economy, which is slowing down and having global impetus on the world economy, e.g. China); ${ }^{42}$

(vi) the sui generis sovereign debt crisis of 2008 and its aftermath resulting in limited fiscal capacities to stimulate the economies (i.e. low real and nominal interest rates, combined with low growth, high debt, and populist pressure, encoding the potential of fiscal crises);

(vii) the fourth industrial revolution (Industry 4.0 together with the Digital Economy fueled by nine technologies (Kovács 2017a)) also triggers uncertainties over its unintended socio-economic and environmental consequences (e.g. whether it is a turning point (bifurcation point) to the becoming of another techno-economic paradigm; what can we say about Industry 4.0 and inequality nexus, Industry 4.0 and productivity nexus, Industry 4.0 and inclusive growth nexus, etc.).

At this point, at least two system-related observations arise. First, by applying a term borrowed from complexity science, these wicked problems seem to be the manifestation of self-organised criticality in the socio-economic innovation ecosystem of today. ${ }^{43}$ These wicked challenges are spanning across the countries' borders, tackling them requires a more systematic understanding of their nature at national, regional and continent-wide levels to have a chance for meaningful re-

${ }^{41}$ There are extensive intra-financial exposures in derivatives markets (European Systemic Risk Board 2016). As a consequence, the beneficial and lively connection between finance and the real economy suffers. Additionally, the non-banking financial companies started to soar in the shadow by leading to bubbles and overvaluation of assets (the shadow-banking exposure of the EU-banks are significant, see Abad et al. (2017: 35)). The parasitic character of the financial sphere is also mirrored in the course of the growing trends in share buy-backs, thereby the players are to boost the stock market. It implies that they are not looking for riskier, but productivity-enhancing investments in the real economy ( $40 \%$ of S\&P 500 firms bought back shares in 1990 , their proportion was $60 \%$ in $1997-2003$, while $85 \%$ of today). It also generates a bias towards larger companies at the expense of the middle ones (Andrews et al. 2016).

42 For the impact of the Chinese economic slowdown (due to its transformation into a more internal oriented, consumption based service economy) on European export dynamics (World Bank 2016).

43 For a system that is in a self-organised critical state, in other words, in a far-from-equilibrium situation with critical instabilities (Prigogine 1997), the magnitude of the next transition is unpredictable, but the long-term probability distribution of event magnitudes is a well-known distribution called "power law" (Aschwanden 2013). 
finement of dominating economic policy toolkit (e.g. systemic risk in the financial system, too-central-to-fail and too-big-to-fail cases, Battiston et al. 2016b). ${ }^{44} \mathrm{Har}-$ monising economic, social and environmental dimensions by affecting complex and non-linear processes within (e.g. euphores for the new technologies and services of the anew technological revolution like Industry $4.0^{45}$ ), what is more, fending off the escalation of anthropogenic climate change require collective action. Importantly, collective action rests upon the capacity of nation states and on common comprehension of ongoing processes that are sought to direct common goals.

Second, our socio-economic innovation ecosystem is a complex system, what is more, is a dissipative system. ${ }^{46}$ Such systems, described by Ilya Prigogine, are open, adaptive, showing irreversibilities in time, and can change course by creating qualitatively new structures. The existence of such system relies heavily and primarily on the flow of energy (i.e. exchanges with the outside world, in our case, the energy is knowledge crystallised in innovation and smart adaptation). An example for such a system is a vortex in the water, whose pattern is dynamic and its shape is sustainable up until the flow of water is guaranteed. Metaphorically, a Heraclitusian economics shall recognise that our socio-economic system is sustainable up until the co-evolution of state and market is synergetic enough to eventuate in capacity building for continuous innovation and smart adaptation. ${ }^{47}$

\section{CONCLUSIONS FOR MODERN ECONOMIC GOVERNANCE}

Our paper portends a dismal prognosis about the policy horizon of economic governance, which is getting ever-more limited as complexity grows. Due to the ever-increasing complexity and the wicked challenges described, no one is fully

44 In so doing, avoiding the tendency toward increasing complexity of regulation is of high importance. See: Krueger - Duncan (1993) who recognised the feedback loops leading to more and more complex regulation.

45 Kovács (2017) demonstrates that fostering Industry 4.0 in China is encoding inefficiency via rent-seeking.

46 A living system is never in full equilibrium, except when it is dead. Thus, a living system, such as the society, is a dissipative system being in far-from equilibrium, and such system per se can also be seen as a self-organised critical system (Kron - Grund 2009; Scheffer 2009), which means that the structure of that system remains for a long time despite the constant flow and change of its components, then a critical state emerges by creating a qualitatively new structure.

47 Beinhocker (2006) envisaged that a gargantuan paradigmatic change is occuring in economics. True, the degree of interdisciplinarity has been increasing (Angrist et al. 2017ab), a complexity-based policy approach has been outlining (OECD 2017), and some courses in economics are more and more streamlined (Bowles 2017), CORE programme, http://econ-core.org. 
in charge, no one can fully scientifically properly overlook ex ante the whole system and all the effects of actions imposed because of complexity. There is, therefore, no fool-proof silver bullet to wicked problems. Moreover, the open, dynamic socio-economic innovation ecosystem does not have by very nature a code filled with elementary and universal laws. It seems that we have reached the end of big theories. ${ }^{48}$

Once economics profession and practitioners are to consider the economy as a complex system, newfangled economic governance with refined policy mix shall emerge $^{49}$ in a more humble way by building on what we once knew and what we still have to learn about complexity.

We argue that the changing course toward a more Heraclitusian Economics - which is more interdisciplinary and appreciates the features of complex dynamic systems, such as interactions, dynamic configuration of processes, nonequilibrium, fundamental uncertainty (unknown unknowns, unexpectedness), emergence and patterns, etc. - is inevitable and it shall be accompanied with pursuing contingency governance. Our paper does by no means aim at drawing comprehensive policy roadmap, but to lay down the basic principles of such governance which are as follows.

Enhancing the stability of trust dynamics: Without trust, any kind of economic governance can fall short because of the political instability. To this end, the following sub-principles are to be pursued by a contingency governance: modesty, decentralisation, collaborative and horizontal mindset, and experimentalism. Since uncertainty is the new norm that calls for modesty in goals and our ability/ capacity via economic policy. Fatal conceit can be reduced and modesty can be bolstered through decentralisation. The higher the degree of decentralised governance, the more fertile ground is given for being closer to the society in a more transparent way leading to more intensive collaboration. Collaborative and horizontal (interdisciplinary, interdepartmental) mindset therefore should be cultivated (i.e. accepting that single-purpose governance entities and departments with silo-thinking are no longer capable of being in a great help, and collaboration is a mechanism to make things sustainable). In this way, building on the literature of higher decentralisation/federalism, a more efficient and faster social learning can be initiated via the series of parallel innovations and smart adaptations that reinforces and enhances the trust infrastructure.

48 Endism was also raised in other stream of economics literature decades ago, namely in development economics (Bookstaber 2017; Musto 1986).

49 Colander - Kupers (2016) led to similar conclusion, but they are still presupposing some convergence towards equilibrium. 
Considerately promoting dynamism in the innovation ecosystem: Complexity science nourishes the message that, beyond stability, society needs amplification, fluctuation and emergence leading to qualitative structural change. The candidate sub-principles in this regard are as follows: festina lente, systems view, differential diagnosis, and equability. With the appearance of the fourth industrial revolution (i.e. cyberphysical systems in smart factories and its ancillary technologies), the principle of make haste slowly (festina lente) together with the principle of system thinking are in order because of the unclear unintended consequences and trade-offs that this development gives rise in the system (concerns over the feasibility of proper cybersecurity; impacts on consumption patterns; concerns over the use of Big Data and nowcasting methods in informing about what is really happening; impact of digitalisation as well as automation on employment, people's mental state, etc.). System thinking means focusing on interactions (e.g. disharmony between the financial sphere and the real economy with its non-linear repercussions) and the intention to creating patterns rather than pursuing numerical static targets. In this way, together with a good deal of critical thinking, more productive governmental investments can be achieved. This has to be made in a differential manner (i.e. there are huge differences across countries in terms of formal and informal institutions as well as regulations). Promoting the bottom-up character of dynamism can manifest in cultivating equability (dampening extreme income and wealth inequality but also outbalancing and unfolding individual opportunities) whereby not only inclusiveness, but talents, and therefore, innovativeness can also be promoted by giving new $e^{\prime} l a n$ into the system's dynamics.

Breeding resilience in the socio-economic innovation ecosystem: the outlined characteristics of complex systems calls for a modern economic governance equipped with the capacities of absorbing shocks, bouncing back (i.e. better informed fiscal and monetary policies ${ }^{50}$ with buffers should be in tandem in providing necessary latitude to navigate through uncertainty; rebuilding more progressive tax systems with the rethinking as well as the retailoring that of the automatic stabilisers by involving the aspect of supporting research and development and innovation), and last but not at all least, transmogrifying its dynamic configuration via putting lessons learnt into practice (i.e. admitting the fact that structural reforms are not the mechanisms directing towards equilibrium, but the perpetual

50 By building on new tools and methods such as complexity narrative techniques, network analysis, evolutionary logic, qualitative scenario thinking, non-linear dynamics, historical analysis and (reverse) stress testing. 
moving mechanisms to make the configuration of processes as much synergetic as possible). ${ }^{51}$

Ultimately, economics must broaden its research canvas by acknowledging what Newton emphasised centuries ago: every scientific field shall find a starting point which is per se unexplained, however, that point is the basis of all explanation. In our case, this is complexity, which forces economics and policymakers to be more humble by not condemning ambivalence. Without pursuing a complexity based economic approach ${ }^{52}$, without acknowledging individual and system-wide interactions (at least most of them), macroeconomics may indeed be doomed and policies tend to fall short in becoming the insturments of a sustainable development value-congruent governance and what any kind of governance will have is just a cacophony of ideas that are nothing more than a theater of empty rhetoric. To this end, all of us should consider complexity economics as a research program rather than a singular theory.

\section{REFERENCES}

Abad, J. - D’Errico, M. - Killeen, N. - Luz, V. - Peltonen, T. - Portes, R. - Urbano, T. (2017): Mapping the Interconnectedness between EU Banks and Shadow Banking Entities. European Systemic Risk Board, Working Paper, No. 40.

Andrews, D. - Criscuolo, C. - Gal, P. A. (2016): The Global Productivity Slowdown, Technology Divergence and Public Policy. Brookings Institute, Hutchins Center Working Paper, No. 24.

Angrist, J. - Azoulay, P. - Ellison, G. - Hill, R. - Feng Lu, S. (2017a): Inside Job or Deep Impact? Using Extramural Citations to Assess Economic Scholarship. NBER Working Paper, No. 23698.

Angrist, J. - Azoulay, P. - Ellison, G. - Hill, R. - Feng Lu, S. (2017b): Economic Research Evolves: Fields and Styles. American Economic Review, 107(5): 293-297.

Arrow, K. J. (1978): The Present and the Future in Economic Life. Economic Inquiry, 16(2): 157169.

Arthur, W. B. (2015): Complexity and the Economy. Oxford University Press.

Aschwanden, M. J. (ed.) (2013): Self-Organized Criticality Systems. Berlin, Warsaw: Open Academic Press.

51 Let us note that Berkeley's principle Esse est percipi does not apply in case of policy measures, which is of paramount importance when it comes to structural reform policies (i.e. a policy measure that was once closed, or the lack of a required policy measure has both meaning and influential power on people's psyche).

52 A larger scale change in economics is thus a sine qua non of better understanding the complex system we live in, however, the reality suggests only tiny fine additions to the current mainstream. For instance, Durlauf (2012) considers complexity thinking in such a fine-tuned and mainly complementary way. 
Assenza, T. - Bao, T. - Hommes, C. - Massaro, D. (2014): Experiments on Expectations in Macroeconomics and Finance. In: Duffy, J. (ed.): Experiments in Macroeconomics (Research in Experimental Economics, Vol. 17). Emerald Group Publishing Limited, pp. 11-70.

Baggott, J. (2017): Mass: The Quest to Understand Matter from Greek Atoms to Quantum Fields. Oxford University Press.

Bak, P. - Tang, C. - Wiesenfeld, K. (1988): Self-Organized Criticality. Physical Review A, 38(1): 364-374.

Battiston, S. - Caldarelli, G. - May, M. R. - Roukny, T. - Stiglitz, J. E. (2016a): The Price of Complexity in Financial Networks. Proceedings of the National Academy of Sciences of the United States of America, Economic Sciences, Physics, 113(36): 10031-10036.

Battiston, S. - Farmer, J. D. - Flache, A. - Galraschelli, D. - Haldane, A. G. - Heesterbeek, H. Hommes, C. - Scheffer, M. (2016b): Complexity Theory and Financial Regulation. Science, Complex Systems, 351(6275): 818-819.

Beinhocker, E. D. (2006): The Origin of Wealth: Evolution, Complexity, and the Radical Remaking of Economics. Harvard Business Review Press.

Bernanke, B. - Gertler, M. (1989): Agency Costs, Net Worth, and Business Fluctuations. The American Economic Review, 79(1): 14-31.

Birkhoff, G. D. (1931): Proof of the Ergodic Theorem. Proceedings of the National Academy of Sciences of the United States of America, 17(12): 656-660.

Blanchard, O. (2016): Do DSGE Models Have a Future? Peterson Institute for International Economics, PIIE Policy Brief, August 2016.

Blanchard, O. - Dell'Ariccia, G. - Mauro, P. (2010): Rethinking Macroeconomic Policy. IMF Staff Position Note, No. 3. Washington, D.C.

Blanchard, O. - Summers, L. H. (2017): Rethinking Stabilization Policy: Evolution or Revolution? NBER Working Paper, No. 24179.

Bloom, N. - Jones, C. I. - Van Reenen, J. - Webb, M. (2017): Are Ideas Getting Harder to Find? NBER Working Paper, No. 23782.

Bookstaber, R. (2017): The End of Theory: Financial Crises, the Failure of Economics, and the Sweep of Human Interaction Hardcover. Princeton University Press.

Boulding, K. E. (1950): A Reconstruction of Economics. New York: Wiley.

Boulding, K. E. (1966): The Verifiability of Economic Images. In: Krupp, S. R. (ed.): The Structure of Economic Science. Prentice Hall: Englewood Cliffs, pp. 129-141.

Bowles, S. (2017): Go Beyond the Sacred Cows of Economics to Understand Change! Il Sole 24 Ore, 31 October 2017.

Byrne, D. M. - Callaghan, G. (2013): Complexity Theory and the Social Sciences: The State of the Art. London: Routledge.

Byrne, D. M. - Fernald, J. G. - Reinsdorf, M. B. (2016): Does the United States Have a Productivity Slowdown or a Measurement Problem? Finance and Economics Discussion Series, No. 2016-017. Board of Governors of the Federal Reserve System. Washington, D. C.

Capra, F. (1996): The Web of Life. A New Scientific Understanding of Living Systems. Anchor; 8/16/97 edition (September 15, 1997).

Capra, F. - Luisi, P. L. (2014): The System's View of Life. Cambridge University Press.

Chang, H-J. (2014): Economics: The User's Guide. U.K.: Pelican.

Christiano, L. J. - Eichenbaum, M. S. - Trabandt, M. (2017): On DSGE Models. Northwestern University, http://faculty.wcas.northwestern.edu/ lchrist/research/JEP_2017/DSGE_final.pdf

Colander, D. - Kupers, R. (2016): Complexity and the Art of Public Policy Solving Society's Problems from the Bottom Up. Princeton University Press. 
Coyle, D. (2012): The Economics of Enough. How to Run the Economy as if the Future Matters. Princeton University Press.

Csaba, L. (2009): Crisis in Economics? Studies in European Political Economy. Budapest: Akademiai Kiadó.

Csaba, L. (2017): Comparative Economics and the Mainstream. Economics and Business Review, 3(3): 90-109.

De Grauwe, P. (2017): The Limits of the Market: The Pendulum Between Government and Market. Oxford University Press.

Diamond, D. W. - Dybvig, P. H. (1983): Bank Runs, Deposit Insurance, and Liquidity. Journal of Political Economy, 91(3): 401-419.

Durlauf, S. N. (2012): Complexity, Economics, and Public Policy. Politics, Philosophy \& Economics, 11(1): 45-75.

Epstein, J. M. (2007): Generative Social Science: Studies in Agent-Based Computational Modelling. Princeton University Press.

Erceg, C. J. - Henderson, D. W. - Levin, A. T. (2000): Optimal Monetary Policy with Staggered Wage and Price Contracts. Journal of Monetary Economics, 46(2): 281-313.

European Systemic Risk Board (2016): Shedding Lights on Dark Markets. First Insights from the New EU-wide OTC Derivatives Dataset. Occasional Paper Series, No 11.

Ferrari-Filho, F. - Conceição, O. A. C. (2005): The Concept of Uncertainty in Post Keynesian Theory and in Institutional Economics. Journal of Economic Issues, 39(3): 579-594.

Frydman, M. - Goldberg, M. D. (2007): Imperfect Knowledge Economics Exchange Rates and Risk. Princeton University Press.

Frydman, M. - Goldberg, M. D. (2011): Beyond Mechanical Markets: Asset Price Swings, Risk, and the Role of the State. Princeton University Press.

Galbraith, J. K. (2014): The End of Normal: The Great Crisis and the Future of Growth. New York: Simon \& Schuster.

Gatti, D. D. - Gaffeo, E. - Gallegati, M. (2008): A Look at the Relationship between Industrial Dynamics and Aggregate Fluctuations. In: Faggini, M. - Lux, T. (eds): Coping with Complexity of Economics. Springer, Series: New Economic Windows, pp. 33-49.

Gatti, D. D. - Gaffeo, E. - Gallegati, M. (2010): Complex Agent-Based Macroeconomics: A Manifesto for a New Paradigm. Journal of Economic Interaction and Coordination, 5(2): 111-135.

Gennaioli, N. - Shleifer, A. - Vishny, R. (2015): Neglected Risks: The Psychology of Financial Crises. American Economic Review Papers and Proceedings, 105(5): 310-314.

Gertler, M. - Kiyotaki, N. (2015): Banking, Liquidity and Bank Runs in an Infinite-Horizon Economy. The American Economic Review, 105(7): 2011-2043.

Gordon, R. J. (2012): Is US Economic Growth Over? Faltering Innovation Confronts the Six Headwinds. NBER Working Paper, No. 18315.

Gürkaynak, R. S. - Kısacıkoğlu, B. - Rossi, B. (2013): Do DSGE Models Forecast More Accurately Out-of-Sample than VAR Models? In: Fomby, T. B. - Kilian, L. - Murphy, A. (eds): VAR Models in Macroeconomics - New Developments and Applications: Essays in Honor of Christopher A. Sims. Advances in Econometrics, Volume 32. Emerald Group Publishing Limited, pp. $27-79$.

Haramein, N. - Brown, W. D. - Val Baker, A. (2016): The Unified Spacememory Network: From Cosmogenesis to Consciousness. NeuroQuantology, 14(4): 657-671.

Hayek, F. A. (1945): The Use of Knowledge in Society. American Economic Review, 35(4): 519530.

Hayek, F. A. (1960): The Constitution of Liberty. Chicago: The University of Chicago Press. 
Hayek, F. A. (1967): The Theory of Complex Phenomena: A Precocious Play on the Epistemology of Complexity. In: von Hayek, F. A. (1967): Studies in Philosophy, Politics and Economics. London: Routledge \& Kegan Paul, pp. 22-42.

Hayek, F. A. (1974): The Pretence of Knowledge. Lecture to the Memory of Alfred Nobel, December $11,1974$.

Heisenberg, W. K. (1958|2000): Physics and Philosophy. The Revolution in Modern Science. 3rd edition, 2000. London: Penguin Books.

Holmström, B. - Tirole, J. (1998): Private and Public Supply of Liquidity. Journal of Political Economy, 106(1): 1-40.

Hommes, C. (2013): Reflexivity, Expectations Feedback and Almost Self-Fulfilling Equilibria: Economic Theory, Empirical Evidence and Laboratory Experiments. Journal of Economic Methodology, 20(4): 406-419.

Hommes, C. (2016): Behavioural Macroeconomics with Heterogeneous Expectations and Interacting Agents. CenDEF Discussion Paper, University of Amsterdam.

Jacobs, S. (1998): Michael Polanyi and Spontaneous Order, 1941-1951. Tradition and Discovery, The Polanyi Society Periodical, 24(2): 14-28.

Kahneman, D. (2011): Thinking, Fast and Slow. U.K.: Allen Lane.

Keen, S. (2017): Can We Avoid Another Financial Crisis? (The Future of Capitalism). Cambridge: Polity Press.

Keynes, J. M. (1921|1973): A Treatise on Probability. Reprinted in: Johnson, E. - Moggridge, D. E. (eds) (1973): The Collected Writings of John Maynard Keynes. Vol. 8., London: Macmillan.

Keynes, J. M. (1930|1971): A Treatise on Money. I. The Pure Theory of Money. Reprinted in: Johnson, E. - Moggridge, D. E. (eds) (1971): The Collected Writings of John Maynard Keynes. Vol. 5. London: Macmillan.

Keynes, J. M. (1936|1973): The General Theory of Employment, Interest and Money. Reprinted in: Johnson, E. - Moggridge, D. E. (eds.) (1973): The Collected Writings of John Maynard Keynes. Vol. 7., London: Macmillan.

Kołodko, G. W. (2011): Truth, Errors and Lies: Politics and Economics in a Volatile World. New York: Columbia University Press.

Kołodko, G. W. (2014a): Whither the World: The Political Economy of the Future. Basingstoke, Hampshire: Palgrave-Macmillan.

Kołodko, G. W. (2014b): The New Pragmatism, or Economics and Policy for the Future. Acta Oeconomica, 64(2): 139-160.

Kornai, J. (1971|1990): Anti-Equilibrium: On Economic Systems Theory and the Tasks of Research (Reprints of Economic Classics). New impression Edition. Augustus M. Kelley Pubs.

Kovács, O. (2017): Az Ipar 4.0 komplexitása - I (Complexity of Industry 4.0 - Part I). Economic Review, 64(6-7): 823-851.

Kron, T. - Grund, T. (2009): Society as a Self-Organised Critical System. Cybernetics and Human Knowing, 16(1-2): 65-82.

Krueger, A. O. - Duncan, R. (1993): The Political Economy of Controls: Complexity. NBER Working Paper, No. 4351.

Krupp, S. R. (1966): The Structure of Economic Science: Essays on Methodology. Prentice-Hall.

LeBaron, B. (2006): Agent-Based Computational Finance. In: Tesfatsion, L. - Judd, K. L. (eds): Handbook of Computational Economics. Elsevier, Vol. 2, pp. 1187-1233.

Marshall, A. (1920): Principles of Economics. London: Macmillan.

Mayr, O. (1971): Adam Smith and the Concept of the Feedback System: Economic Thought and Technology in 18th-Century Britain. Technology and Culture, 12(1): 1-22. 
Monaghan, J. J. - Kajtar, J. B. (2014): Leonardo da Vinci's Turbulent Tank in Two Dimensions. European Journal of Mechanics - B/Fluids, 44(3-4): 1-9.

Morin, E. (2007): Restricted Complexity, General Complexity. In: Gershenson, C. - Aerts, D. Edmonds, B. (eds): Worldviews, Science and Us: Philosophy and Complexity. Singapore: World Scientific, pp. 5-29.

Musto, S. A. (1987): Die hilflose Hilfe. Ansätze zu einer Kritik der manipulativen Vernunft. In: Schwefel, D. (ed.) (1987): Soziale Wirkungen von Projekten in der Dritten Welt. Baden-Baden: Nomos, pp. 419-503.

Muth, J. F. (1961): Rational Expectations and the Theory of Price Movements. Econometrica, 29(3): 315-335.

Nolan, B. - Roser, M. - Thewissen, S. (2016): GDP per Capita versus Median Household Income: What Gives Rise to Divergence over Time? Oxford: INET Working Paper Series, No. 3.

OECD (2017a): OECD Economic Outlook 2017. Paris.

OECD (2017b): New Approaches to Economic Challenges. Towards a New Narrative. OECD Forum 2017. Paris.

Perez, C. (2009): Technological Revolutions and Techno-Economic Paradigms. Cambridge Journal of Economics, 34(1): 185-202.

Polanyi, M. (1939): The Rights and Duties of Science. The Manchester School, 10(2): 175-193.

Polanyi, M. (1941): The Growth of Thought in Society. Economica, New Series, 8(32): 428-456.

Prigogine, I. (1990): Time, Dynamics and Chaos. Integrating Poincaré's “Non-integrable Systems”. University of Texas, Austin, TX (USA). Center for Studies in Statistical Mechanics and Complex Systems.

Prigogine, I. (1997): The End of Certainty. Time, Chaos, and the New Laws of Nature. New York: Free Press.

Prigogine, I. - Stengers, I. (1984): Order out of Chaos: Man's New Dialogue with Nature. New York: Bantam Books.

Ravallion, M. - Chen, S. (2017): Welfare-Consistent Global Poverty Measures. NBER Working Paper, No. 23739.

Reaume, D. M. (1996): Walras, Complexity, and Post Walrasian Macroeconomics. In: Colander, D. (ed.) (1996): Beyond Microfundations. Post Walrasian Economics. Cambridge Unversity Press, Chapter 9, pp. 145-156.

Rosenblueth, A. - Wiener, N. - Bigelow, J. (1943): Behavior, Purpose and Teleology. Philosophy of Science, 10(1): 18-24.

Rosser, J. B. Jr. (2006): Complex Dynamics and Post Keynesian Economics. In: Setterfield, M. (ed.) (2006): Complexity, Endogenous Money and Macroeconomic Theory. Essays in Honour of Basil J. Moore. Edward Elgar Publishing, pp. 74-98.

Röpke, W. (1950): Mass und Mitte. Zürich: Orell Füssli Verlag.

Scheffer, M. (2009): Critical Transitions in Nature and Society. Princeton University Press.

Schwarzkopf, Y. - Axtell, R. L. - Farmer, J. D. (2011): An Explanation of Universality in Growth Fluctuations. Santa Fe Institute, U.S.

Shleifer, A. (2012): Psychologists at the Gate: A Review of Daniel Kahneman's Thinking, Fast and Slow. Journal of Economic Literature, 50(4): 1-12.

Simon, H. A. (1947): Administrative Behavior. New York: Macmillan.

Simon, H. A. (1962): The Architecture of Complexity. Proceedings of the American Philosophical Society, 106(6): 467-482.

Simon, H. A. (1978): Rational Decision-Making in Business Organizations. Lecture to the Memory of Alfred Nobel, December 8, 1978.

Soros, G. (2003): The Alchemy of Finance. 2nd Edition. John Wiley \& Sons, Inc. 
Stigler, G. J. (1957): Perfect Competition, Historically Contemplated. Journal of Political Economy, 65(1): $1-17$.

Teulings, C. - Baldwin, R. (eds) (2014): Secular Stagnation: Facts, Causes and Cures. A VoxEU. org Book, CEPR Press.

Verhulst, F. (2016): Henri Poincaré's Inventions in Dynamical Systems and Topology. In: Skiadas, C. (ed.): The Foundations of Chaos Revisited: From Poincaré to Recent Advancements. Understanding Complex Systems. Springer, pp. 1-25.

von Neumann, J. V. (1932): Proof of the Quasi-Ergodic Hypothesis. Proceedings of the National Academy of Sciences of the United States of America, 18(1): 70-82.

Walras, L. (1900|1954): Elements of Pure Economics. London: Allen and Unwin.

World Bank (2016): The Impact of China on Europe and Central Asia. Europe and Central Asia Economic Update. Office of the Regional Chief Economist, April 2016.

Zingales, L (2013): Preventing Economists' Capture. In: Carpenter, D. - Moss, D. (eds): Preventing Regulatory Capture: Special Interest Influence and How to Limit It. Cambridge University Press.

Open Access. This is an open-access article distributed under the terms of the Creative Commons Attribution 4.0 International License (https://creativecommons.org/licenses/ by/4.0), which permits unrestricted use, distribution, and reproduction in any medium, provided the original author and source are credited, a link to the CC License is provided, and changes - if any - are indicated. (SID_1) 